\title{
Domestic dogs in Atlantic forest preserves of south-eastern Brazil: a camera-trapping study on patterns of entrance and site occupancy rates
}

\author{
Srbek-Araujo, AC. and Chiarello, AG.* \\ Programa de Pós-Graduação em Zoologia de Vertebrados, \\ Pontifícia Universidade Católica de Minas Gerais - PUC Minas, \\ Av. Dom José Gaspar, 500, Bairro Coração Eucarístico, CEP 30535-610, Belo Horizonte, MG, Brazil \\ *e-mail: bradypus@pucminas.br
}

Received February 12, 2007 - Accepted August 10, 2007 - Distributed November 30, 2008

(With 3 figures)

\begin{abstract}
Presence of exotic species in forest remnants is a major concern for the conservation of wild species, not only on islands, where potential impact is higher. Although the problem is widespread and increasing, there are few studies on Neotropical forests. Here we quantify the occurrence of domestic dogs (Canis lupus familiaris) in an Atlantic forest reserve in south-eastern Brazil (Santa Lúcia Biological Station - SLBS). Throughout two years of monitoring with camera traps (2,142 camera-days), 25 records of 16 individual dogs were obtained in the interior of SLBS, making dogs the fourth most frequently recorded species of mammals in general and the first-ranking among Carnivora, ahead of the ocelot and puma, the top two terrestrial predators present in SLBS. Dogs entered the forest year round, in almost half of the sampled months (48\%), and predominantly during daytime (89\%). They were detected in various trails inside the reserve, but mostly in areas nearest to the reserve's border ( $<200 \mathrm{~m}$ from the edge). Record rates of domestic dogs did not correlate significantly with climate variables, with frequency of mammal records and richness in general, or with any particular mammal species (Spearman rank correlation, $p>0.05$ in all cases), suggesting an erratic, nonseasonal pattern of entrance in the reserve. Data indicate that domestic dogs can be abundant and frequent visitors to little disturbed Atlantic forest reserves even when these are located in regions of low density of human population. The potential impact to native fauna is discussed.
\end{abstract}

Keywords: Atlantic forest, camera traps, Canis lupus familiaris, domestic dogs, exotic species.

\section{Cães-domésticos em remanescentes de Mata Atlântica no sudeste do Brasil: padrões de entrada e de ocupação obtidos a partir de armadilhas fotográficas}

\begin{abstract}
Resumo
A presença de espécies exóticas em remanescentes florestais é um dos maiores problemas para a conservação de táxons silvestres, não apenas em ilhas, onde o impacto potencial do contato entre os grupos citados revela-se mais significativo. Apesar deste problema ser amplo e crescente, poucos são os estudos desenvolvidos em florestas Neotropicais. Neste sentido, o presente estudo objetivou caracterizar a presença de cães-domésticos (Canis lupus familiaris) em uma reserva de Mata Atlântica localizada no Sudeste do Brasil (Estação Biológica de Santa Lúcia - EBSL). A partir de dois anos de monitoramento com armadilhas fotográficas (2.142 câmeras-dia), foram obtidos 25 registros de 16 indivíduos no interior da EBSL. Com relação ao número de registros obtidos, o cão-doméstico foi a quarta espécie mais registrada, considerando a mastofauna de maneira geral, e a primeira entre os Carnivora, estando à frente da jaguatirica e da onçaparda, os dois principais predadores terrestres presentes na EBSL. Os cães-domésticos entraram na reserva durante todo o ano, apresentando registros em quase metade dos meses de amostragem (48\%), predominantemente ao longo do dia (89\%). Os espécimes foram detectados em várias trilhas no interior da EBSL, principalmente em áreas próximas à borda reserva (<200 $\mathrm{m}$ da borda). A taxa de registros de cão-doméstico não esteve significativamente correlacionada com variáveis climáticas, com a frequiência de registros e a riqueza de mamíferos em geral, ou com alguma espécie de mamífero em particular (Correlação de Spearman, $\mathrm{p}>0,05$ em todos os casos), sugerindo uso errático e não sazonal da reserva. Os dados obtidos indicam que os cães-domésticos podem se tornar visitantes abundantes e freqüentes em pequenos remanescentes de Mata Atlântica, mesmo quando estes estão localizados em regiões com baixa densidade populacional humana. O potencial impacto do cão-doméstico sobre a fauna silvestre é discutido.
\end{abstract}

Palavras-chave: armadilha fotográfica, Canis lupus familiaris, cão doméstico, espécies exóticas, Mata Atlântica. 


\section{Introduction}

Domestic animals can impact native fauna in several ways, including increased predation (Lepczyk et al., 2004; Kays and DeWan, 2004), especially on islands (Burbidge, 1999; Anderson et al., 2006), and genetic introgression (Vilà and Wayne, 1999; Adams et al., 2003), which sometimes might disturb the genetic integrity of native species (Pierpaoli et al., 2003). Disease transmission seems, however, to be the most important disturbance effect in many continental countries (Cleaveland et al., 2000; Frolich et al., 2000; Anderson et al., 2003; Hammer et al., 2004). Past studies have explored the presence of domestic dogs in wild areas or their impact on wild species (Herranz et al., 2002; Butler et al., 2004; Manor and Saltz, 2004; Anderson et al., 2006), however few studies have been conducted in Neotropical forests. These include predation on native species (Kruuk and Snell, 1981; Barnett and Rudd, 1983), potential disease transmission (Ryan et al., 2003; Fiorello et al., 2004; Deem and Emmons, 2005; McFadden et al., 2005; Fiorello et al., 2006), and social biology of free-roaming dogs (Daniels and Bekoff, 1989; Fielding and Mather, 2001). In Brazil there is some information of domestic dog impacts on native fauna (Horowitz, 1992; Lacerda, 2002; Galetti and Sazima, 2006), observation of dog attacks to other domestic animals (Oliveira and Cavalcanti, 2002; Cavalcanti, 2003), dog presence in protected areas (Alves, 2003; Srbek-Araujo and Chiarello, 2005) and potential disease transmission (Courtnay et al., 2001). However, to the best of our knowledge this is the first in-depth study focused on the quantification of domestic dog presence in a conservation unit located in the Atlantic forest area. The Atlantic forest is one of the richest and most threatened forest biomes in the world (Myers et al., 2000). The degree of threat is rooted in five centuries of development, which has been greatly accelerated in the last 150 years (Dean, 1995). Today, about $70 \%$ of the Brazilian population (about 100 million people) lives within the original area of this biome, including world megalopolis like São Paulo and Rio de Janeiro (Galindo-Leal and Câmara, 2003). As the urban areas spread, the contact of domestic animals with wild animals increases and so does the potential for disease transmission, predation and possible competition with native animals. Here we analyzed data on frequency of records, number of individuals, the spatial and temporal patterns of records and the interaction between native mammals and dogs, in a little-disturbed and well-preserved Atlantic forest reserve in south-eastern Brazil. These data are important to better assess the potential impact of dogs on Neotropical mammals, and are also important for planning management strategies of conservation units located in an increasingly urban environment.

\section{Methods}

\subsection{Study area}

The study was carried out in the 440 ha Santa Lúcia Biological Station (SLBS; $19^{\circ} 57^{\prime} 10^{\prime \prime}-19^{\circ} 59^{\prime} 00^{\prime \prime} \mathrm{S}$ and $40^{\circ} 31^{\prime} 30^{\prime \prime}-40^{\circ} 32^{\prime} 25^{\prime}$ ' W), located $6 \mathrm{~km}$ from the urban center of Santa Teresa city (Figures 1 and 2). Santa Teresa is a small town with circa 20,000 inhabitants, the most part of which inhabit the rural area. With adjoining private land, the area of native forest in which SLBS is located totals circa 900 ha (Figures 1 and 2). Altitudes vary from 550 to $950 \mathrm{~m}$ (Mendes and Padovan, 2000). The weather is predominantly Cfa in Koppen's classification, being characterized by a hot and wet season (OctoberMarch) and a dry and cold season (April-September); average precipitation is $1,868 \mathrm{~mm}$ and average annual temperature is $19.9{ }^{\circ} \mathrm{C}$ (Mendes and Padovan, 2000). Predominant vegetation is dense ombrophilous (wet) Forest (IBGE, 1993). Native forest remnants (north and west), agriculture (mainly coffee) and Eucalyptus plantations (south and east) are the predominant vegetation surrounding SLBS. A small number of rural residences are found neighboring SLBS, especially in the south and east areas. Due to high levels of species richness and endemism, this region is considered of extreme biological importance for the conservation of the Atlantic Forest (Conservation International, 2000). The nonvolant mammal fauna of SLBS is rich, with 21 families and 51 species already confirmed and actually present in the reserve (Passamani et al., 2000; Srbek-Araujo and Chiarello, 2005). Other faunal groups and the flora are similarly diverse (Thomaz and Monteiro, 1997; Brown Jr. and Freitas, 2000). Further information about SBLS and region is found in Thomaz and Monteiro (1997) and Mendes and Padovan (2000).

\subsection{Data collection}

The study was based on camera-trapping in SLBS from February 2002 to February 2004. In a previous study, the camera data were used to discuss mammal diversity in this reserve and compare the efficiency of this technique to more traditional inventory methods (Srbek-Araujo and Chiarello, 2005). Throughout the monitoring, three camera traps of the model Wildlife Pro Camera, made by Forest Suppliers Inc. (USA), and four camera traps of the model Deer Cam - Scouting Camera, made by Non Typical Inc. (USA), were used. Both brands of equipment use $35 \mathrm{~mm}$ automatic cameras with passive infrared sensors that detected motion and variations of heat in a detection cone beginning at the camera. Negative 200 ASA films of 36 exposures were used. The interval between photos was set to minimum (20 and 30 seconds for the first and second brands, respectively) and cameras operated 24 hours throughout the study. Camera traps were installed in tree trunks ca $45 \mathrm{~cm}$ from the ground, preferably along trails and in margins of small creeks. The cameras were checked every 15-30 days for maintenance, changing of films and battery if necessary. No baits were used since these could influence natural behavior of dogs and native mammal species (Cutler and Swann, 1999).

Sampling period encompassed 25 occasions of approximately 30 days each from February 2002 to February 


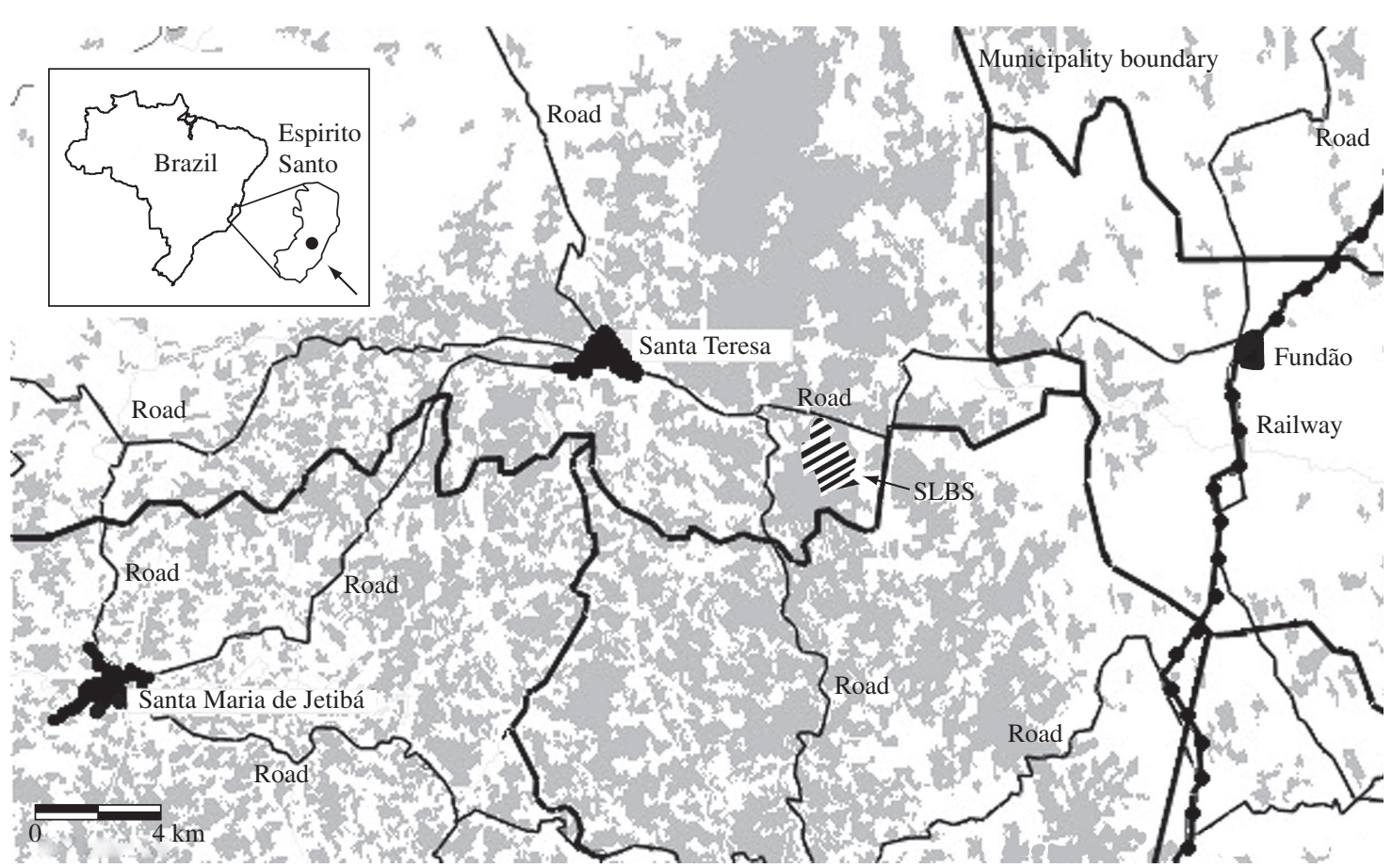

Figure 1. Map of the study region in center-south Espírito Santo state (inset) showing forest fragments (grey areas), three urban areas (black areas: Santa Teresa, Santa Maria do Jetibá and Fundão), roads (thin lines) and municipality borders (thick lines). The approximate location of the study area (Santa Lúcia Biological Station - SLBS) is also shown (striped area). Modified from the image of Fundação SOS Mata Atlântica and Instituto de Pesquisas Espaciais (2004), available at: http://www. sosmataatlantica.com.br.

2004. From December 2002 to November 2003 camera traps were installed in pairs (two units at each sampling location, allowing recording both sides of a pictured mammal). In all other periods they were installed singly. A total of 28 sampling points distributed in 12 trails were sampled, with a minimum distance of $300 \mathrm{~m}$ between each other. The area sampled by camera traps, calculated using the minimum convex polygon method (without any buffer) totaled 157.8 ha. Given malfunctioning equipment throughout the study, the number of sampling points varied from two to three/month (see below). Further details are found in Srbek-Araujo and Chiarello (2005). Additionally, visits were carried out in rural residences located nearby SLBS (Penha, Valsugana Velha and Santa Lúcia districts) aiming to locate and identify the residence of domestic dogs photographed by the camera traps inside the reserve. When this was possible, the residence-to-sampling point distance (straight line distance) was measured using a GPS (Garmin Etrex) instrument. To help find the residences of domestic dogs, one of us (ACSA) participated in a field campaign of vaccination against rabies carried out by the Environmental Surveillance Department of the Santa Teresa municipality (Setor de Vigilância Ambiental em Saúde - SVAS) in November 2003. Several residences of the rural area were visited during this campaign. The distance between the sampling point where a given dog was photographed inside SLBS and the nearest forest edge was also measured using the GPS.

\subsection{Data analysis}

We calculated two types of records, depending on the analysis. For analysis on interspecific comparisons we considered the area covered by camera traps as the sampling unit and only one record per species per day was included (heretofore record type 1). This approach was judged necessary due to the small distance between adjacent sampling points (300 $\mathrm{m}$ ), which cannot be considered as statistically independent one from another, and also due to the relatively small size of sampled area (157.8 ha). Further, given that the number of camera traps effectively functioning varied from month to month, we used record rates (number of type 1 records/camera trapdays) instead of number of records. The type 1 record, being restrictive, diminishes the chance of a same individual of a given species being photographed repeatedly during the sampling period, which would inflate the frequency of records (i.e., record rate) of this species in comparison to others. So the type 1 record was regarded as a less biased estimator of record rates when several species are compared (see Martins and Sanderson, 2006 for a relevant discussion on this). To check if frequency of domestic dogs in SLBS varied according to climate we used two approaches. First, we correlated the monthly record rates of domestic dogs with climate variables (monthly total of rainfall and average monthly temperature, both gauged in a weather station located in SLBS) using the Spearman rank correlation. Second, we 


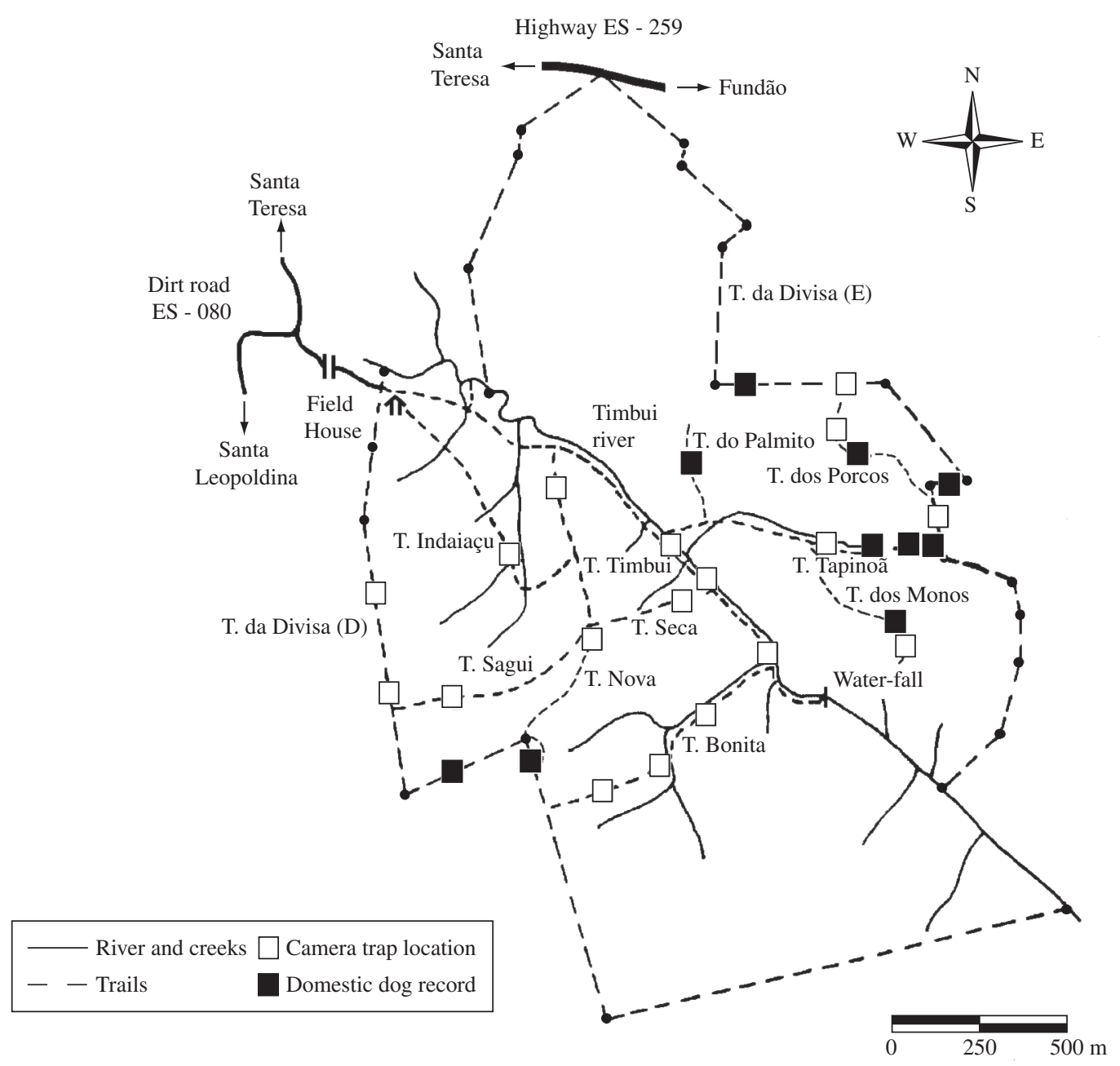

Figure 2. Map of Santa Lúcia Biological Station showing camera-trapping locations where domestic dogs were recorded (filled squares) and those locations where dogs were not recorded (empty squares). Modified from Mendes and Padovan (2000).

compared differences in record rates of dogs, wild mammals and species record rates (number of species of wild mammals/camera trap-days) between dry season months (April to September) and wet season months (October to March) using the Mann-Whitney test. Further, we used backward stepwise logistic regression to investigate if the monthly presence of domestic dogs was related to corresponding record rate of wild mammals (all species pooled), or to species record rates. For this, the monthly presence (1) or absence (0) of domestic dogs in SLBS was considered the dependent binary variable, and four independent variables were tested: 1) monthly record rates of wild mammals, 2) monthly species record rates of wild mammals, 3 ) monthly total of rainfall and 4) average monthly temperature. Default settings of SPSS were used for variable selection and model fitting.

To analyze the activity period, identify individual dogs and investigate the spatial and temporal patterns of domestic dog records in the reserve we used a sec- ond record type (heretofore record type 2). This record was defined as a picture of dog taken at less than fiveminute intervals in the same camera trap point (when $>1$ record was taken within 5 minutes, only one record was considered). The counting of records when cameras were placed in pairs was done disregarding simultaneous records taken (for each pair of simultaneous records, only one record was counted). For these periods, each pair of camera traps was considered a single sampling unit. When more than one individual of a given species was captured in a picture, only one record of the species was counted. Type 2 records were classified into nocturnal, diurnal and crepuscular using the software Earthsun version 4.6 (W. Scott Thoman, 830 Panel Road, Macedon, New York, USA). This program uses data on coordinates, date and altitude, to calculate the exact time of sunrise, sunset, start and end of twilight for each sampling day. All analyses, variable selection and model fitting were performed using the default settings of the 
SPSS software, version 8.0. Mammal taxonomy follows the most recent edition of Wilson and Reeder (2005).

\section{Results}

The 25 months of monitoring in SLBS resulted in a sampling effort of 2,142 camera-days. This effort totaled 292 (type 1) records of 21 species of native mammals, plus two other unidentified species (one small rodent and one marsupial) (Table 1; see also Srbek-Araujo and Chiarello, 2005). A total of 25 (type 1) or 36 (type 2) records of 16 domestic dogs (Canis lupus familiaris) were obtained. In two records we were unable to identify the individual dog (only part of the animal was photographed). Overall, the domestic dog was the fourth species in number of records and the top ranking among nine species of Carnivora, closely ahead of the ocelot (Leopardus pardalis), with 24 records (type 1). Only six species were recorded in $>40 \%$ of sampled months, and the domestic dog was among these, with an average record rate of 1/month (range $0-8$ records/month).

There were no significant correlations between climate variables and record rates (type 1) of dogs (rainfall: $r_{\mathrm{s}}=-0.366 ; \mathrm{n}=22 ; \mathrm{p}=0.094$; temperature: $\mathrm{r}_{\mathrm{s}}=-0.080$; $\mathrm{n}=21 ; \mathrm{p}=0.730$ ), nor between climate variables and record rate of native mammals (rainfall: $\mathrm{r}_{\mathrm{s}}=0.012 ; \mathrm{n}=22$; $\mathrm{p}=0.956$; temperature: $\left.\mathrm{r}_{\mathrm{s}}=-0.149 ; \mathrm{n}=21 ; \mathrm{p}=0.520\right)$. Monthly record rate of domestic dogs did not correlate significantly with corresponding record rates of wild mammals $(n=23)$ tested individually (Spearman rank correlation; $p>0.05$ in all 23 cases). Logistic regression also failed to detect a significant relationship between the monthly presence of domestic dogs in SLBS and the corresponding record rate (type 1) of native mammals [Cox and Snell R² 0.197 ; of the four tested independent

Table 1. Total number of type 1 records of mammals obtained from February 2002 to February 2004 of camera trapping in Santa Lúcia Biological Station, Brazil. The number of months with records and the average and range of records/month are also shown. For comparative purposes, species are arranged in decreasing number of records. See Methods for details.

\begin{tabular}{|c|c|c|c|c|c|c|}
\hline \multirow[t]{2}{*}{ Species } & \multicolumn{2}{|c|}{ Records } & \multicolumn{2}{|c|}{ Month } & \multicolumn{2}{|c|}{ Records/month } \\
\hline & Number & $\%$ & Number & $\%$ & Mean & Range \\
\hline Dasyprocta leporina (Linnaeus, 1758) & 44 & 15.07 & 19 & 76.0 & 1.76 & $0-8$ \\
\hline Didelphis aurita Wied-Neuwied, 1826 & 44 & 15.07 & 15 & 60.0 & 1.76 & $0-11$ \\
\hline Cuniculus paca (Linnaeus, 1766) & 27 & 9.25 & 11 & 44.0 & 1.08 & $0-6$ \\
\hline Canis lupus familiaris (Linnaeus, 1758) & 25 & 8.56 & 12 & 48.0 & 1.00 & $0-8$ \\
\hline Leopardus pardalis (Linnaeus, 1758) & 24 & 8.22 & 15 & 60.0 & 0.96 & $0-4$ \\
\hline Metachirus nudicaudatus (Desmarest, 1817) & 15 & 5.14 & 12 & 48.0 & 0.60 & $0-2$ \\
\hline Procyon cancrivorus (G. Cuvier, 1798) & 15 & 5.14 & 8 & 32.0 & 0.60 & $0-4$ \\
\hline Dasypus novemcinctus Linnaeus, 1758 & 14 & 4.79 & 8 & 32.0 & 0.56 & $0-4$ \\
\hline Puma concolor (Linnaeus, 1771) & 12 & 4.11 & 8 & 32.0 & 0.48 & $0-3$ \\
\hline Mazama gouazoubira (G. Fischer, 1814)* & 11 & 3.77 & 7 & 28.0 & 0.44 & $0-3$ \\
\hline Nasua nasua (Linnaeus, 1766) & 11 & 3.77 & 8 & 32.0 & 0.44 & $0-2$ \\
\hline Pecari tajacu (Linnaeus, 1758) & 9 & 3.08 & 7 & 28.0 & 0.36 & $0-2$ \\
\hline Rodentia unidentified & 8 & 2.74 & 6 & 24.0 & 0.32 & $0-2$ \\
\hline Cabassous sp.** & 6 & 2.05 & 4 & 16.0 & 0.24 & $0-2$ \\
\hline Cerdocyon thous (Linnaeus, 1766) & 6 & 2.05 & 5 & 20.0 & 0.24 & $0-2$ \\
\hline Sylvilagus brasiliensis (Linnaeus, 1758) & 5 & 1.71 & 5 & 20.0 & 0.20 & $0-1$ \\
\hline Sciurus aestuans Linnaeus, 1766 & 4 & 1.37 & 3 & 12.0 & 0.16 & $0-2$ \\
\hline Eira barbara (Linnaeus, 1758) & 3 & 1.03 & 3 & 12.0 & 0.12 & $0-1$ \\
\hline Leopardus tigrinus (Schreber, 1775) & 2 & 0.68 & 2 & 8.0 & 0.08 & $0-1$ \\
\hline Puma yagouaroundi (Lacépède, 1809) & 2 & 0.68 & 2 & 8.0 & 0.08 & $0-1$ \\
\hline Didelphimorphia unidentified & 2 & 0.68 & 2 & 8.0 & 0.08 & $0-1$ \\
\hline Euphractus sexcinctus (Linnaeus, 1758) & 1 & 0.34 & 1 & 4.0 & 0.04 & $0-1$ \\
\hline Hydrochoerus hydrochaeris (Linnaeus, 1766) & 1 & 0.34 & 1 & 4.0 & 0.04 & $0-1$ \\
\hline Philander frenatus (Olfers, 1818) & 1 & 0.34 & 1 & 4.0 & 0.04 & $0-1$ \\
\hline Total & 292 & 100.00 & 25 & 100.0 & 11.70 & $0-11$ \\
\hline
\end{tabular}

*In a previous study (Srbek-Araujo and Chiarello, 2005) this deer species was identified as M. americana. Further comparisons carried out after publication indicated, however, that the correct pictured species is M. gouazoubira. **Cabassous tatouay have been collected in the region of Santa Teresa, but the poor quality of pictures obtained in the present study does not guarantee an unequivocal identification. 
variables (rainfall, temperature, record rate and species record rate), only rainfall was included in the final model, but with a marginal significance $(R=-0.192 ; p=0.080)]$. Nevertheless, direct interaction between domestic dogs and native mammal species was recorded on a single occasion: at 07:33 hours an agouti (Dasyprocta leporina) was recorded foraging on the ground in front of the camera trap and at 09:11 hours of that same day a domestic dog was photographed sniffing the exact spot were the agouti had foraged less than two hours earlier.

Regarding now the records of type 2, domestic dogs were detected in 10 of the 28 sampling points, distributed in half $(n=6)$ of all 12 sampled trails. The average distance between sampling points (with dog records) and nearest forest edge was $365.4 \mathrm{~m}$ (range $=0-1,100 \mathrm{~m}$ ). Controlling for differences in sampling effort among sampling locations, there was a slightly higher number of domestic dog records in the two first class of distances to the nearest edge (0-399 m) (Figure 3). It was possible to determine the location of dog residence (human settlement) for only two of the 16 photographed dogs: a single house distant 668 and $948 \mathrm{~m}$ from the corresponding sampling points inside SLBS. No other dog photographed in SLBS was found or located during the vaccination campaign carried out in residences located nearby this reserve.

Dogs of various sizes were recorded but mediumsized ones predominated. Only one individual was young, the others were all adults or sub-adults. Both males $(n=6)$ and females $(n=4)$ were recorded (sex discrimination was possible in $62.5 \%$ of cases). Domestic dogs were photographed alone (72.2\% of records) or in groups (couple of individuals; $27.8 \%$ of records) (7 different pairs were photographed). Pair formation was recorded in 10 occasions and some individuals were paired with different dogs in some occasions. Most pairs

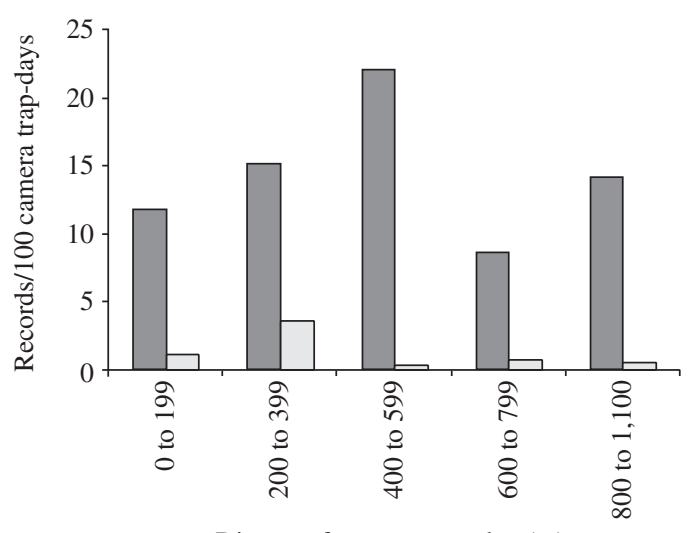

Distance from nearest edge $(\mathrm{m})$

Wild mammals Domestic dogs

Figure 3. Record rate of mammals and domestic dogs in relation to distance to nearest forest edge in Santa Lúcia Biological Station.
(57.1\%) were composed by at least one female (all four females identified were photographed mostly in pairs). Most dogs $(n=9 ; 56.3 \%)$ entered the reserve in a sporadic way, being photographed only once during the study; the remaining individuals $(\mathrm{n}=7 ; 43.7 \%)$ were recorded two to thirteen times each, within intervals that varied from less than one hour to eight months in between. Domestic dogs were recorded predominantly during the day ( $\mathrm{n}=32$ records; $88.9 \%$ ), two records were nocturnal and two during the twilight period.

\section{Discussion}

Our results show that a high number of records were near the reserve's border with agriculture, where rural human residences are closer (the eastern portion of SLBS). These results are in accordance with Odell and Knight (2001), which states that domestic species are detected most frequently in areas nearby human residences or places with a high density of houses. On the other hand, the western portion of SLBS, where far fewer records were obtained, is contiguous to a large tract of native forest, which therefore is likely acting as a buffer, hampering the entrance of dogs. Similarly, the occurrence of dogs in Brasília National Park (a reserve located in Cerrado, close to the Brazilian Capital, Brasilia) was more influenced by external characteristics (dogs were seen most frequently near to developing urban and rural areas) than to internal factors of that Park, such as type of vegetation (Lacerda, 2002). So the frequent occurrence of dogs near to the borders of SLBS can be viewed as a type of edge effect (Murcia, 1995; Laurance et al., 2002), as also suggested by Lacerda (2002). The small number of individuals identified in residences near SLBS might suggest that most dogs recorded within this reserve either came from more distant areas, or are not pet dogs at all, being part of the errant (or feral) dog population of the region. Either way, an expressive number of recorded individuals $(43.7 \%)$ entered this reserve repeatedly. In another Atlantic forest preserve of Brazil, Galetti and Sazima (2006) considered the study dog population as "feral", although no evidence/explanation for this categorization were detailed.

According to Manor and Saltz (2004), one of the consequences of forest fragmentation is the decreasing distance between native forest and urban zones and the consequent entrance of dogs in undisturbed areas. This is the case here. The distance between SLBS and the closest town (Santa Teresa) is short, roughly $6 \mathrm{~km}$. Additionally, two thirds $(68 \%)$ of the human population of Santa Teresa municipality (20,709 inhabitants; IBGE 2003) live in rural areas. Considering that most (if not all) residences located in rural areas have at least one domestic dog each (a conservative estimate), the number of dogs potentially able to enter the reserve must be very high. According to the Environmental Surveillance Department (SVAS), the domestic dog population of Santa Teresa municipality is estimated to be between 2,078 and 3,464 dogs, as- 
suming ratios of $1: 10$ and $1: 6$ in relation to the human population, respectively (Secretaria Municipal de Saúde, 2003). These results stress the need for urgent control of dog entrance in conservation units even in areas of low human population density and relatively high cover of native forests.

Although the analyses presented here failed to reveal significant relationship between domestic dogs and native mammals (i.e., potential prey), local residents and previous researchers have reported instances of dogs pursuing native mammal species such as brocket deer (Mazama spp.), armadillos (Dasypus spp., Euphractus sexcinctus, Cabassous sp.), agoutis (Dasyprocta leporina), paca (Cuniculus paca), and even primates (Callicebus personatus), suggesting that they do act as predators. Also, the comparison of record rates among species indicate that domestic dog is locally more abundant than the top terrestrial predator present in SLBS, the puma (Puma concolor), and perhaps even more so than the ocelot, a medium-sized cat. In fact, comparing stripe patterns and other external signals, seven individual ocelots and two pumas were identified in the area sampled by camera traps in SLBS, much lower figures than that of domestic dogs (16 individuals). Although the real numbers and population densities are not know, these results clearly suggest that domestic dogs might be abundant enough to potentially impact the local community of terrestrial mammals, perhaps even more so than the native terrestrial predators. In Brazil, Horowitz (1992) and Lacerda (2002) report the occurrence of dogs pursuing native mammals and the death of species due to dog attacks in Brasília National Park, although the stomach contents analyzed $(n=18)$ indicated the presence of garbage, young domestic birds among other items, but no remains of native species were found (Lacerda, 2002). According to Oliveira and Cavalcanti (2002), in most attacks the domestic dog would not kill the animal or the dog would not feed on the killed prey. Similarly, Lacerda (2002) states the attacks would be related to instinctive predator-prey games rather than to hunting for obtaining food. On the other hand, the study of Galetti and Sazima (2006) lists a total of 46 carcasses of 12 species (including amphibians, reptiles, birds and specially mammals) predated by domestic dogs in Santa Genebra reserve throughout 44 months of study. But as these authors did not witness the attacks, some of the putative prey could have been scavenged rather than predated.

Beside their role as predators, dogs can impact a native community also through competition. Butler et al. (2004) mention that domestic dogs are a least significant competitor of the large African predators, due to their very low ability of taking large prey. In the Neotropics, dogs could potentially compete with large cats, like jaguars (Panthera onca) and pumas (Puma concolor), and with smaller carnivores (ocelots - Leopardus pardalis, crabeating foxes - Cerdocyon thous, among others), but data are still lacking to substantiate this. On the other hand, dogs can be preyed upon by native species (Butler et al., 2004). Farrel et al. (2000), for example, found remains of domestic dogs in puma scats in Venezuela. Although this might be considered positive as it represents a way of naturally controlling the dog population inside conservation units, it is also a mechanism of transmission of dog diseases and parasites to native mammals.

According to the Environmental Surveillance Department (SVAS) of Santa Teresa, from March 2002 to December 2003, 328 free-roaming dogs were removed from residences and public streets or roads of the municipality, most of which $(68.0 \%)$ were sacrificed (the remaining returned to their owners or were adopted by others). Two important actions are enforced by this sector: disease control (Rabies and Leishmaniasis, through vaccination of healthy individuals and the sacrifice of sick dogs) and control of the free-roaming population (capture and elimination). Since the beginning of SVAS's activities, only one case of bovine rabies was confirmed in Santa Teresa (March 2003). Regarding Leishmaniasis, 15 dogs were suspected to be infected in 2002 and four in 2003 (four animals were sacrificed in the first and one in the second year, after positive confirmation via lab analysis) (Secretaria Municipal de Saúde, 2003; 2004). In this sense, this program might be indirectly contributing to the preservation of native mammal species, eliminating or greatly diminishing the population of potential vectors of diseases. According to Haass et al. (1996), for example, at least eight of the 11 extant families of carnivores are susceptible to canine distemper virus. Such actions (zoonosis control) should thus be included in the list of priorities for conservation of native species, especially in contact zones such as the rural environment and areas close to conservation units (Butler et al., 2004).

Data here presented indicate that domestic or freeroaming dogs can be frequent visitors to wet tropical forests preserves of the Neotropics. Although results did not indicate a close relationship with native mammals, the abundance and temporal distribution of dog records do suggest a high potential for impact on community ecology and health of wild mammal species. It is wise, therefore to put into practice efficient measures aiming directly at the control of the canine population and the prophylaxis of diseases potentially transmitted by these animals. To be effective this control should be carried out within conservation units as well as outside them and the latter should include rural as well as urban zones. Although staff of conservation units in both the Atlantic forest and Cerrado of Brazil have to deal with this problem almost on a daily basis (pers. obs.), an integrated official agenda for domestic dog control is still to be accorded and implemented. It is equally necessary to promote the education of the human population living in cities and in rural areas, stressing the importance of keeping dogs responsibly. These animals should be well fed, vaccinated and not allowed to wander freely without being in the company, or under the control, of their owners. Although these practices are common sense in 
developed countries, its use and implementation in the third world is still in its infancy. Such measures will assume increasing importance as a conservation strategy, given the expected increase in human population, and the consequent increase in number of domestic animals, in most countries of the Neotropics.

Acknowledgements - We are greatly indebted to all the staff of the Museu de Biologia Professor Mello Leitão, specially its director Hélio de Q. B. Fernandes and secretary Rose Loss. The Setor de Vigilância Ambiental em Saúde, especially André P. Fontana, kindly helped with information about the local dog population and zoonosis. Eduardo M. de Barros, Leandro S. Moreira, Luciana Barçante, Marina N. dos Santos, Oscar Echevery, Paula L. Ruiz, Pedro Amaral, Rodrigo L. Meyer, Sérgio P. Costa and Valeska B. de Oliveira kindly helped with data collection. One of us (ACSA) was granted a research fellowship from the Brazilian Federal Agency CAPES. This project was funded by the Conselho Nacional de Desenvolvimento Científico e Tecnológico/CNPQ (grant \# 469.321/2000-8) and the Fundo de Incentivo à Pesquisa - PUC Minas (grant \# FIP 2002/06-TLE). AGC has a productivity grant (bolsa produtividade em pesquisa) from CNPQ (grant \# 301100/2005-5)

\section{References}

ADAMS, JR., LEONARD, JA. and WAITS, LP., 2003. Widespread occurrence of a domestic dog mitochondrial DNA haplotype in southeastern US coyotes. Mol. Ecol., vol. 12, no. 2, p. $541-546$.

ALVES, LCPS., 2003. Uso de armadilhas fotográficas no levantamento da mastofauna da Reserva Biológica de Araras, $I E F-R J$. Juiz de Fora: Universidade Federal de Juiz de Fora. [Bachelor dissertation].

ANDERSON, TC., FOSTER, GW. and FORRESTER, DJ., 2003. Hookworms of feral cats in Florida. Vet. Parasitol., vol. 115 , no. 1 , p. $19-24$.

ANDERSON, CB., ROZZI, R., TORRES-MURA, JC., MCGEHEE, SM., SHERRIFFS, MF., SCHÜTTLER, E. and ROSEMOND AD., 2006. Exotic vertebrate fauna in the remote and pristine sub-Antarctic Cape Horn Achipelago, Chile. Biodivers. Conserv., vol. 15, no. 10, p. 3295-3313.

BARNETT, BD. and RUDD, RL., 1983. Feral Dogs of the Galapagos Islands: Impact and Control. International Journal for the study of Animal Problem, vol. 4, no. 1, p. 44-58.

BROWN Jr., KS. and FREITAS, AVL., 2000. Diversidade de Lepidoptera em Santa Teresa, Espírito Santo. Bol. Mus. Biol. Mello Leitão, vol.11/12, p. 71-116.

BURBIDGE, AA., 1999. Conservation values and management of Australian islands for non-volant mammal conservation. Australian Conservation, vol. 21, no. 1, p. 67-74.

BUTLER, JRA., DU TOIT, JT. and BINGHAM, J., 2004. Freeranging domestic dogs (Canis familiaris) as predators and prey in rural Zimbabwe: threats of competition and disease to large wild carnivores. Biol. Conserv., vol. 115, no. 3, p. 369-378.

CAVALCANTI, SM., 2003. Manejo e controle de danos causados por espécies da fauna. In: CULLEN Jr., L., RUDRAN, R. and VALLADARES-PADUA, C. (Eds.). Métodos de Estudos em Biologia da Conservação e Manejo da Vida Silvestre. Curitiba: Universidade do Paraná.
CLEAVELAND, S., APPEL, MGJ., CHALMERS, WSK., CHILLINGWORTH, C., KAARE, M. and DYE, C., 2000. Serological and demographic evidence for domestic dogs as a source of canine distemper virus infection for Serengeti wildlife. Vet. Microbiol., vol. 72, no. 3-4, p. 217-227.

CONSERVATION INTERNATIONAL, 2000. Avaliação $e$ Ações Prioritárias para a Conservação da Biodiversidade da Mata Atlântica e Campos Sulinos. Brasília: Conservation International.

COURTNAY, O., QUINNEL, RJ. and CHALMERS, WSK., 2001. Contact rates between wild and domestic canids: no evidence of parvovirus or canine distemper virus in crab- 19 eating foxes. Vet. Microbiol., vol. 81, no. 1, p. 9-19.

CUTLER, TL. and SWANN, DE., 1999. Using remote photography in wildlife ecology: a review. Wildl. Soc. Bull., vol. 27 , no. 3 , p. $571-581$

DANIELS, TJ. and BEKOFF, M., 1989. Population and social biology of free-ranging dogs, Canis familiaris. J. Mammal., vol. 70, no. 4, p. 754-762.

DEAN, W., 1995. With the Broadax and Firebrand, the Destruction of the Brazilian Atlantic Forest. Berkeley: University of California Press.

DEEM, SL. and EMMONS, LH., 2005. Exposure of freeranging maned wolves (Chrysocyon brachyurus) to infectious and parasitic disease agents in the Noel Kempff Mercado National Park, Bolivia. J. Zoo. Wildl. Med., vol. 36, no. 2, p. $192-197$

FARREL, LE., ROMAN, J. and SUNQUIST, ME., 2000. Dietary separation of sympatric carnivores identified by molecular analysis of scats. Mol. Ecol., vol. 9, no. 10, p. 1583-1590.

FIELDING, WJ. and MATHER, J., 2001. Dog ownership in the west Indies: a case study from the Bahamas. Anthrozoos, vol. 14 , no. 1 , p. $72-80$.

FIORELLO, CV., DEEM, SL., GOMPPER, ME. and DUBOVI, EJ., 2004. Seroprevalence of pathogens in domestic carnivores on the border of Madidi National Park, Bolivia. Anim. Conserv., vol. 7 , no. 1 , p. $45-54$

FIORELLO, CV., NOSS, AJ. and DEEM, SL., 2006. Demography, Hunting Ecology, and Pathogen Exposure of Domestic Dogs in the Isoso of Bolivia. Conserv. Biol., vol. 20, no. 3, p. 762-771.

FROLICH, K., CZUPALLA, O., HAAS, L., HENTSCHKE, J., DEDEK, J. and FICKEL, J., 2000. Epizootiological investigations of canine distemper virus in free-ranging carnivores from Germany. Vet. Microbiol., vol. 74, no. 4, p. 283-292

FUNDAÇÃO SOS MATA ATLÂNTICA and INSTITUTO DE PESQUISAS ESPACIAIS, 2004. Atlas dos Municípios da Mata Atlântica. <http://www.sosmataatlantica.com.br>. Cited Nov 2004.

GALETTI, M. and SAZIMA, I., 2006. Impacto de cães ferais em um fragmento urbano de Floresta Atlântica no sudeste do Brasil. Natureza e Conservação, vol. 4, no. 1, p. 58-63.

GALINDO-LEAL, C. and CÂMARA, I.G., 2003. Atlantic forest hotspot: An overview. In: GALINDO-LEAL, C. and CÂMARA, IG. (Eds). The Atlantic Forest of South America. Biodiversity Status, Threats, and Outlook. Washington: Island Press. p. 3-11. 
HAASS, L., HOFER, H., EAST, M., WOHLSEIN, P., LIESS, B. and BARRETT, T., 1996. Canine distemper virus infection in Serengeti spotted hyaenas. Vet. Microbiol., vol. 49, no. 1-2, p. $147-152$

HAMMER, AS., DIETZ, HH., ANDERSEN, TH., NIELSEN, L. and BLIXENKRONE-MOELLER, M., 2004. Distemper virus as a cause of central nervous disease and death in badgers (Meles meles) in Denmark. Vet. Rec., vol. 154, no. 17, p. $527-530$

HERRANZ, J., SUAREZ, F. and YANES, M., 2002. A low-cost photographic system to identify predators of ground-nesting bird nests. Game and Wildlife Science, vol. 19, no. 3, p. 179-195.

HOROWITZ, C., 1992. Plano de Manejo do Parque Nacional de Brasília: Avaliação da Metodologia de Planejamento adotada, Execução e Resultados Alcançados no Decênio 79/89. Brasília: Universidade de Brasília. [Master Dissertation].

IBGE, 1993. Mapa de Vegetação do Brasil. Fundação Instituto Brasileiro de Geografia e Estatística. Rio de Janeiro: IBGE.

-, 2003. Instituto Brasileiro de Geografia e Estatística. $<$ <ttp://www.ibge.gov.br>. Cited Nov 2004.

KAYS, RW. and DEWAN, AA., 2004. Ecological impact of inside/outside house cats around a suburban nature preserve. Anim. Conserv., vol. 7, no. 3, p. 273-283.

KRUUK, H. and SNELL, H., 1981. Prey selection by feral dogs from a population of marine iguanas (Amblyhynchus cristatus). J. Appl. Ecol., vol. 18, no. 1, p. 197-204

LACERDA, ACR., 2002. Análise de ocorrência de Canis familiaris no Parque Nacional de Brasília: influência da matriz, monitoramento e controle. Brasília: Universidade de Brasília. [Master Dissertation].

LAURANCE, WF., LOVEJOY, TE., VASCONCELOS, HL., BRUNA, EM., DIDHAM, RK., STOUFFER, PC., GASCON, C., BIERREGAARD, RO., LAURANCE, SG. and SAMPAIO, E., 2002. Ecosystem decay of Amazonian Forest fragments: a 22year investigation. Conserv. Biol., vol. 16, no. 3, p. 605-618.

LEPCZYK, CA., MERTIG, AG. and LIU, J., 2004. Landowners and cat predation across rural-to-urban landscapes. Biol. Conserv., vol. 115, no. 2, p. 191-201.

MANOR, R. and SALTZ, D., 2004. The impact of free-roaming dogs on gazelle kid/female ratio in a fragmented area. Biol. Conserv., vol. 119, no. 2, p. 231-236.

MARTINS, SS. and SANDERSON, JG., 2006. Monitoring mammals in the Caxiuanã National Forest, Brazil - First results from the Tropical Ecology Assessment and Monitoring (TEAM) program. Biodiversity and Conservation. in press.

MCFADDEN, KW., WADE, SE., DUBOVI, EJ. and GOMPPER, ME., 2005. A Serological and Fecal Parasitologic Survey of the Critically Endangered Pygmy Raccoon (Procyon pygmaeus). J. Wildlife Dis., vol. 41, no. 3, p. 615-617.

MENDES, SL. and PADOVAN, MP., 2000. A Estação Biológica de Santa Lúcia, Santa Teresa, Espírito Santo. Bol. Mus. Biol. Mello Leitão, vol. 11/12, p. 7-34.
MURCIA, C., 1995. Edge effects in fragmented forests: implications for conservation. Trends Ecol. Evol., vol. 10, no. 2, p. 58-62.

MYERS, N., MITTERMEIER, RA., MITTERMEIER, CG., FONSECA, GAB. and KENT, J., 2000. Biodiversity hotspots for conservation priorities. Nature, vol. 403, no. 6772, p. 853-858.

ODELL, EA. and KNIGHT, RL., 2001. Songbird and medium-sized mammal communities associated with exurban development in Pitkin country, Colorado. Conserv. Biol., vol. 15 , no. 4 , p. 1143-1150.

OLIVEIRA, TG. and CAVALCANTI, SMC., 2002. Identificação de Predadores de Animais Domésticos. In: PITMAN, MRPL., OLIVEIRA, TGR., PAULA, C. and INDRUSIAK, C. (Eds.). Manual de Identificação, Prevenção e Controle de Predação por Carnívoros. Brasília: Instituto Brasileiro de Meio Ambiente e Recursos Naturais. p. 31-50.

PASSAMANI, M., MENDES, SL. and CHIARELlO, AG., 2000. Non-volant mammals of the Estação Biológica de Santa Lúcia and adjacent areas of Santa Teresa, Espírito Santo, Brazil. Bol. Mus. Biol. Mello Leitão, vol. 11/12, p. 201-214.

PIERPAOLI, M., BIRÒ, ZS., HERMANN, M., HUPE, K., FERNANDES, M., RAGNI, B., SZEMETHY, L. and RANDI, E., 2003. Genetic distinction of wildcat (Felis silvestris) populations in Europe, and hybridization with domestic cats in Hungary. Mol. Ecol., vol. 12, no. 10, p. 2585-2598.

RYAN, PR., ARANA, BA., RYAN, JR., WIRTZ, RA., WORTMANN, GW. and RIZZO, NR., 2003. The domestic dog, a potential reservoir for Leishmania in the Peten Region of Guatemala. Vet. Parasitol., vol. 115, no. 1, p. 1-7.

SECRETARIA MUNICIPAL DE SAÚDE, 2003. Relatório Anual da Secretaria Municipal de Saúde de Santa Teresa/Setor de Vigilância Ambiental em Saúde - Ano 2002. Final Report. Unpublished Report. Santa Teresa: Secretaria Municipal de Saúde.

-, 2004. Relatório Anual da Secretaria Municipal de Saúde de Santa Teresa/Setor de Vigilância Ambiental em Saúde Ano 2003. Final Report. Unpublished Report. Santa Teresa: Secretaria Municipal de Saúde.

SRBEK-ARAUJO, AC. and CHIARELLO, AG., 2005. Is camera-trapping an efficient method for surveying mammals in neotropical forests? A case study in south-eastern Brazil. $J$. Trop. Ecol., vol. 21, no. 1, p. 121-125.

THOMAZ, LD. and. MONTEIRO, R., 1997. Composição florística da Mata Atlântica de encosta da Estação Biológica de Santa Lúcia, município de Santa Teresa - ES. Bol. Mus. Biol. Mello Leitão, vol. 7, p. 3-48.

VILÀ, C. and WAYNE, RK., 1999. Hibridación entre Perros y Lobos. Conserv. Biol., vol. 13, no. 1, p. 195-198.

WILSON, DE. and REEDER, DM., 2005. Mammal species of the World. A taxonomic and geographic reference. 3 ed. Washington: Johns Hopkins University Press. 